\title{
Lighting and noise level in the central facilities of the Costa Rican Distance Education University: health implications for staff and students
}

\author{
Lourdes Arce Espinoza ${ }^{1}$ and Julián Monge-Nájera² \\ ${ }^{1}$ Servicio Médico, Universidad Estatal a Distancia, 474 - 2050 San Pedro Montes de Oca, San José-Costa Rica; larce@uned.ac.cr \\ ${ }^{2}$ Vicerrectoría de Investigación, Universidad Estatal a Distancia, 474 - 2050 San Pedro Montes de Oca, San José-Costa Rica; julianmonge@gmail.com
}

Received 7-XII-2009 Corrected 11-I-2010 Accepted 3-III-2010

\begin{abstract}
Physical agents of the workplace such as noise and light affect work performance, productivity and quality. Noise can cause insomnia, mood changes, hearing loss and, in pregnant women, fetal damage, and it can promote the development of cardiovascular disease. Poor lighting generates tear production, eye strain and headaches, and increases accident rate. From June 08 through October 23, 2009 we used digital devices to measure noise and lighting in several rooms of the Costa Rican Distance Education University. The rooms were selected because they have noisy machinery or require a particular degree of illumination (printing facilites, warehouse and library). We found that both light levels and noise are inadequate in these departments where a quiet and well-lighted environment is basic to the daily activity and health of staff and students. We recommend the installation of noise dampers, the mandatory use of ear protectors and a redesign of artificial lighting in those specific rooms of the institution.
\end{abstract}

\section{KEY WORDS}

Occupational health, work environment, physical factors, sick building, occupational hazards.

\section{RESUMEN}

Los agentes físicos del ambiente laboral, como el ruido y la iluminación, afectan el desempeño, la productividad y la calidad del trabajo. Es por esto que su estudio ha tomado importancia en los últimos años. El ruido puede causar insomnio, cambios de humor, pérdida auditivay-en mujeres embarazadas- daño en el feto, y favorecer el desarrollo de enfermedad cardiovascular. La iluminación deficiente, por su parte, genera lagrimeo, fatiga visual y cefalea, $y$ favorece los accidentes laborales. Del 08 de junio al 23 de octubre del 2009 estudiamos, con medidores electrónicos, los niveles de ruido e iluminación en los lugares de la Universidad Estatal a Distancia de Costa Rica que utilizan maquinaria generadora de ruido o requieren un nivel especial de iluminación (imprenta, almacén y biblioteca). Encontramos que tanto los niveles de iluminación como de ruido son inadecuados en departamentos de la UNED donde esos niveles son clave para el desempeño diario y para la salud del personal y el estudiantado. Recomendamos la instalación de amortiguadores de ruido, el uso obligatorio de protectores auditivos y un rediseño de la iluminación en esos sitios concretos de la institución.

\section{PALABRAS CLAVE}

Salud ocupacional, ambiente laboral, agentes físicos, edificio enfermo, riesgo laboral.
Physical factors such as lighting, noise and heat are present in all human activities and when they exceed certain limits, they can damage health (Rodríguez \& Alonzo 2004).

Inadequate lighting is a major risk factor, because even though every activity requires manual, intellectual and visual skills, about $80 \%$ of the information reaching the brain to perform everyday tasks is visual. Furthermore, light directly influences the worker's disposition towards the task and therefore affects production. Light is particularly critical when a task requires precision: in that case, a poorly lit room quickly causes fatigue (Guerrero et al. 2006).

Other effects of bad lighting, because of insufficient or excess, are stress, headaches and visual disturbances (Rodríguez \& Alonzo 2004). For example tear secretion dysfunction in woman workers exposed to low humidity, flashing light, and low ambient illumination is high and increases with time (Su et al. 2006). But the effects of inadequate illumination and unnatural light cycles can be even more serious: they may increase breast cancer risk 
through several mechanisms, including increased estrogen production and altered estrogen receptor function (Stevens 2005). Inadequate illumination can also favor ground-operation accidents in airports (Wang \& Zhang 2007).

Sound is a vibration of an elastic medium, perceived as unpleasant. Land and air traffic, infrastructure building, roads and industrial activity, are among the main sources of harmful noise (Chávez 2007).

It has long been known that loud noise produced by military activities and industrial machinery produces various pathologies. The main increase in exposure to noisy work environments came after the English industrial revolution and, for example in the USA, it affects 30 million people (Hernández \& Gutierrez 2006). More recently it has been realized that slight noise also is an environmental pollutant that can cause physical and psychological disorders in the short, medium and long term (Ahmed et al. 2001, Standard INTE 31-09-16-97).

One of the most important and studied effects of noise is hearing loss, but noise also produces previously unknown or underestimated disorders that include loss of concentration, sleep disorders, learning deficit, stress, cardiovascular problems, chronic fatigue, communication interference, and aggressiveness. In pregnant women it can cause poorly developed fetuses (Chávez 2007).

In Latin America, noise was generally perceived as a harmless contaminant. Medical personnel normally becomes involved only when deafness occurs, ignoring that the damage resulting from constant exposure is cumulative and long term (Sanchez \& Cristhian 2006). Ignorance by staff prevented an atmosphere beyond prevention of occupational deafness (Gómez et al. 2008).

We analyzed lighting and noise levels in areas of greatest risk in one of the largest open universities of Latin America, the Distance Education University (San Jose, Costa Rica), which has more 22000 students.

\section{METHODOLOGY}

Noise measurements were done from June 8 through August 25, 2009. We selected this period because it is the peak activity period of the university press. Light was measured from 18 September through 23 October, 2009.

Measurements were taken at different periods of the workday in order to contemplate changes in the natural lighting that reached the rooms, which also have artificial illumination (fluorescent lamps).

\section{Lighting}

We made a total of 20 light level measurements in three units of the university: Library, General Warehouse and
University Press Workshop. In the library we sampled 61 points (warehouse 23 points; press 20 points).

We chose these sites because the library is a place that requires clearly defined levels of light for reading and proper study; and the general warehouse and press shop because their staff does hard physical work and there is the risk of falls and other accidents. Danger is especially great in the press, where staff operates hazardous industrial machinery. We used a HD450 Extech light meter.

The measurements were grouped according to the requirements stated in the Standard INTECO 31-08-06-2000. For all measurement points in the warehouse and press workshop, the standard establishes a minimum of 300 lux. The minimum for the library is 400 lux.

\section{Noise}

We made 20 noise measurements in 71 points of the workshop, with a certified Extech sound level meter (octave band; real time). We chose the workshop because it has the highest noise levels in the institution (industrial machinery).

To sort the results we considered 85 decibels as the maximum level and measurements were classified as green (under 80 decibels), yellow (over 80 and under 85 decibels) and red (85 decibels or higher).

The measurements were grouped according to the requirements stated in the Standard INTECO 31-09-16-2000.

\section{RESULTS}

\section{Lighting}

At the workshop, half of the measuring points have insufficient illumination (Fig. 1). In the warehouse and the library, all the points had insufficient illumination (Fig. 2).

The results were distributed into two groups: green (met the recommendations) and red (excess).

At the workshop and warehouse the Green subgroup averaged 344,94 lux (minimum 300,7 - maximum 400; standard deviation 26,06 lux: the rest of the data follows the same format). For the Red subgroup, the mean was 173,40 (from 4,3 to 299,4; SD 81,07 lux).

In the library (Fig. 3) the Green subgroup had an mean of 400 (400,00 to 400,00 SD 0 lux) and for the Red subgroup, the mean was $142,7(0,2$ to 396,$7 ;$ SD 98,89 lux).

\section{Noise}

Noise in the workshop varied widely depending on location, but it was excessive in almost two thirds of the sites 


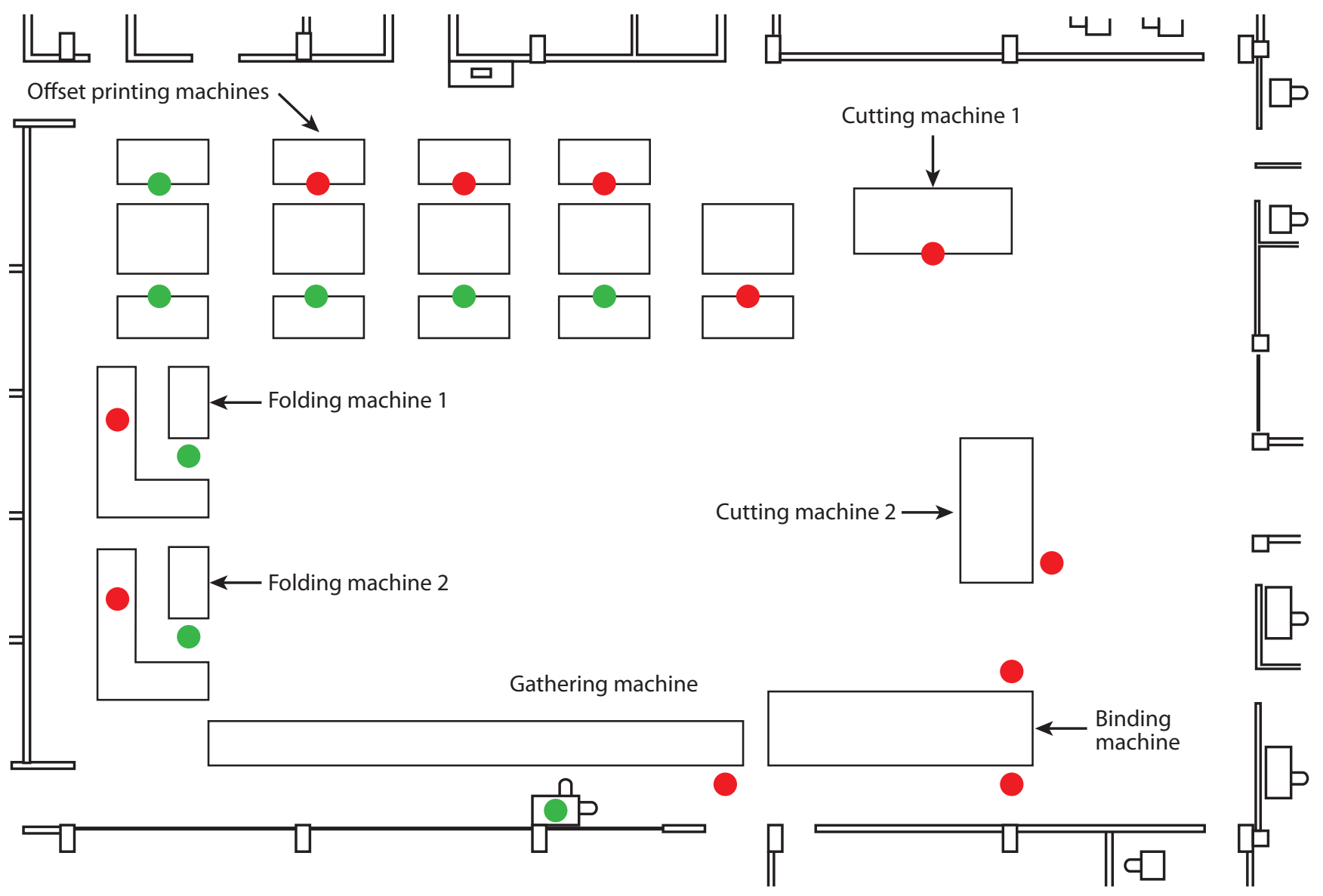

FIG. 1. Distribution of lighting levels in the workshop of Editorial UNED. Map not to scale. Mann-Whitney $U, p=0,0000$.

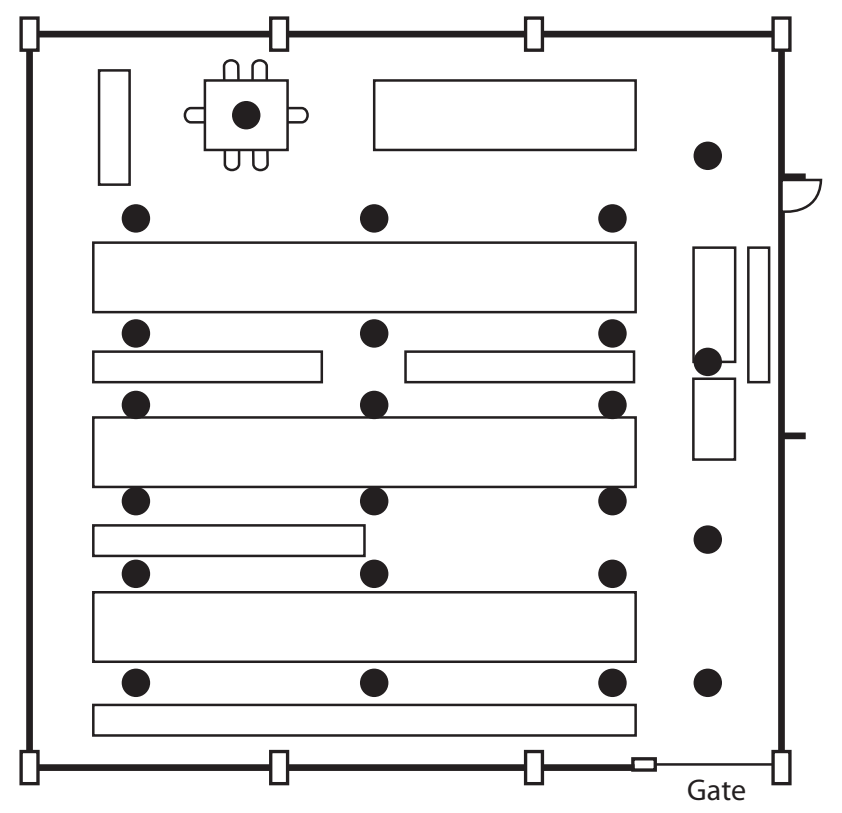

FIG. 2. Distribution of lighting levels in the General Warehouse of Editorial UNED. Map not to scale. Mann-Whitney $U, p=0,0000$. measured (Fig. 4). In the Green subgroup the mean was $79,2(69,5$ to 79,$9 ;$ SD 1,95 decibels) in the Yellow subgroup 82,63 (80-85; of 1,41 decibels) and in the red subgroup, $88,33(85,1$ to 105,$7 ;$ SD 3,61 decibels).

\section{DISCUSSION}

\section{Lighting}

At the workshop, half of the measuring points have insufficient lighting. All the measurement points have insufficient illumination in the warehouse and the library

In the case of the library, poor lighting can cause fatigue, headache or excessive teardrop production (Guerrero et al. 2006), but the potential effects are more severe in the warehouse and workshop. In addition to fatigue, stress, headaches and visual disturbances (Rodríguez \& Alonzo 2004), in the warehouse and workshop, the low light levels can cause lower production output per hour 


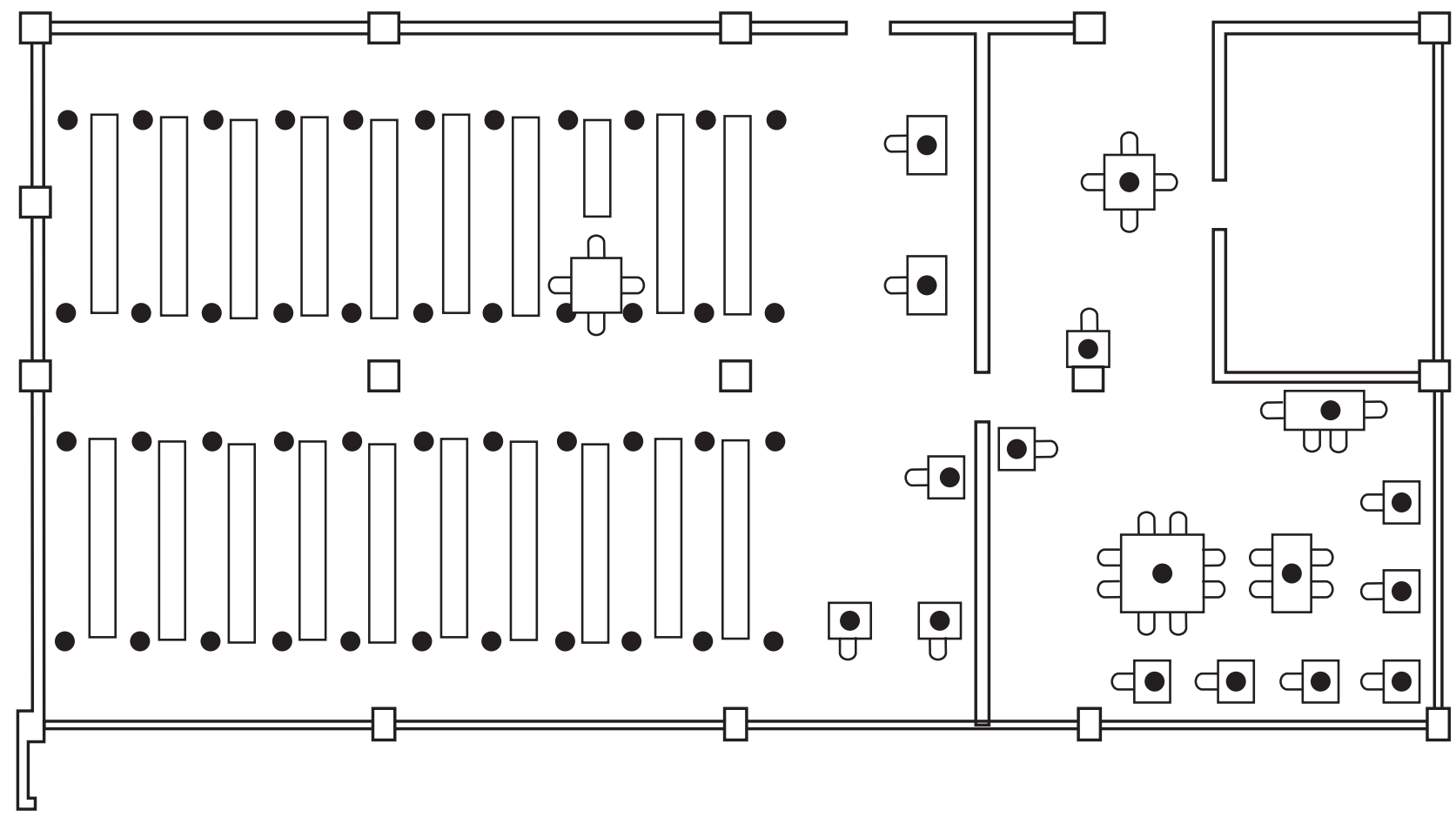

FIG. 3. Distribution of lighting levels in the Library, UNED. Map not to scale. Mann-Whitney U, $p=0,0000$.

of work, and accidents (Wang \& Zhang 2007). These are particularly serious because the workhouse has hydraulic machinery and there is a risk of heavy boxes and materials falling from shelves, and of staff falls. Similarly, danger is high in the workshop, where workers use large guillotines and presses.

\section{Noise}

At the workshop, international standards indicate that the noise level is excessive in almost two thirds of the points measured. But even in points where noise received the "Green" label, it far surpassed 45 decibels. Other studies have concluded that even these intermediate levels can cause communication interference, aggression and poor fetal development (Chávez 2007). They are also associated with chronic fatigue, as was found in a recent study on the effects of noise in Italy (Kluizenaar \& Janssen 2009). In turn, the continuous exposure to high noise levels does not allow recovery of the hearing threshold and therefore the initial symptoms of exposure, such as irritability, persist for long periods (Otárola et al. 2008).

At the workshop, noise exceeds the level that can interfere with complex tasks, decreasing attention and altering choice of task strategy. This can lead to increased anxiety and even to consumption of sedative medication (Stansfeld 2006, La Torre et al. 2007). It also causes a release of stress hormones, which in turn adversely affect cardiovascular risk factors (Selander et al. 2009). The noise levels in the shop are also associated with a risk of occurrence of Arterial Hypertension and Myocardial Infarction, but only for men (Babisch et al. 2005., Belojevi et al. 2008).

For the high risk to health that noise has in that department, it is essential that workshop personnel routinely use ear protectors and receive health monitoring.

This study found that both light levels and noise are inadequate in the UNED departments where these levels are key to the daily activity and health of staff and students. We recommend the installation of noise dampers, the mandatory use of ear protectors and a redesign of the lighting in those specific sites in the institution.

\section{ACKNOWLEDGMENTS}

We thank René Muiños Gual and the University Press workshop staff, Elver Castro Monge and the General Warehouse staff, and Rita Hernández Ledezma and the staff of the Library. We also thank Andrea Sánchez Guevara for her help with obtaining and processing information. 


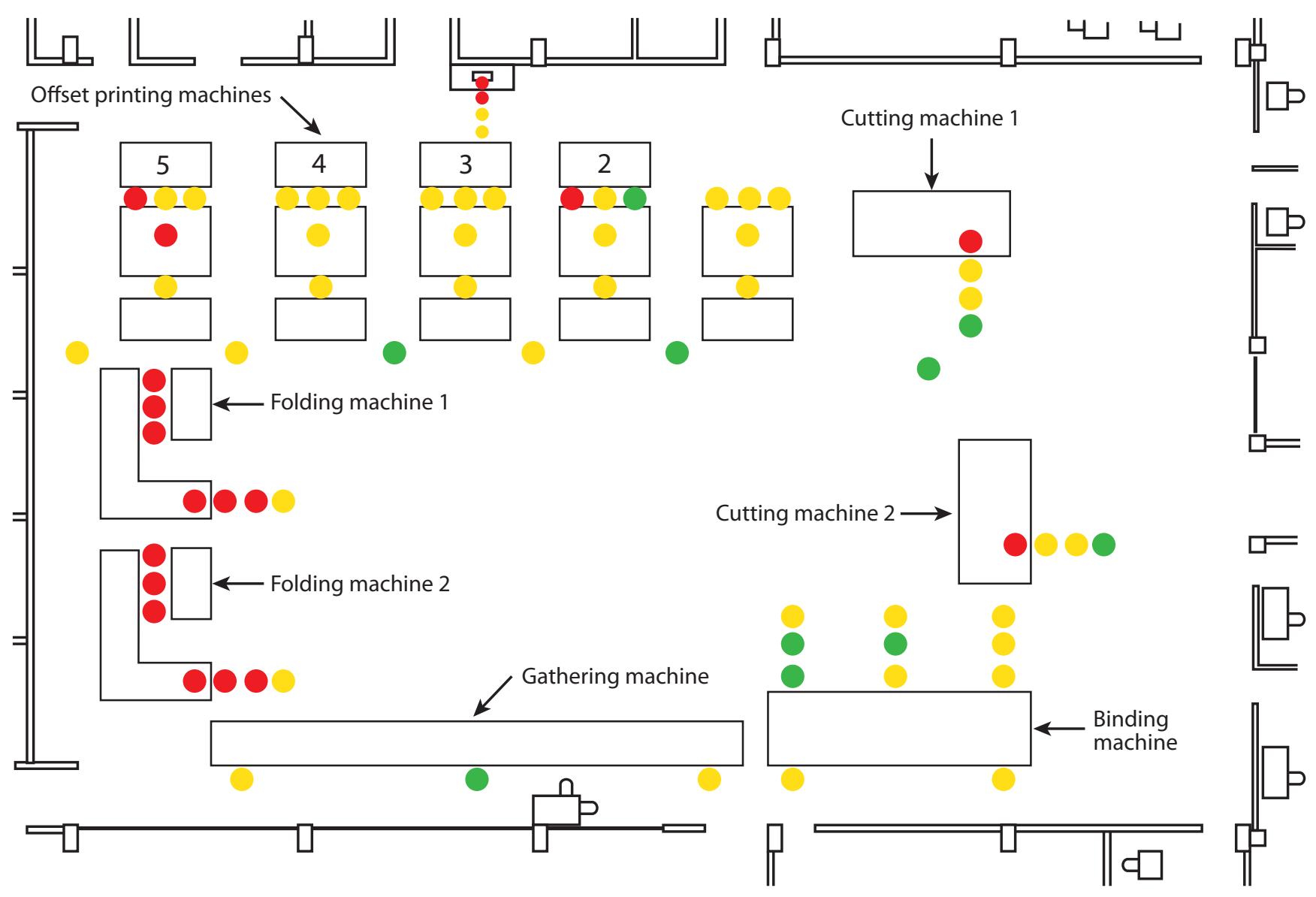

FIG. 4. Distribution of noise levels in the workshop of Editorial UNED. Map not to scale. Kruskal Wallis ANOVA H = 997, $p=0,0000$.

\section{REFERENCES}

Ahmed, H.O., J.H. Dennis, O. Badran, M. Ismail, S.G. Ballal, A. Ashoor, A. \& D. Jerwood. D. 2001. Occupational noise exposure and hearing loss of workers in two plants in eastern Saudi Arabia. Occupational Hygiene 45:371-380.

Babisch, W., B. Beule, M. Schust, N. Kersten \& H. Ising. 2005. Traffic Noise and Risk of Myocardial Infarction. Epidemiology 16:33-40.

Belojevi G.A, B. D. Jakovljevi, V. J. Stojanov, V. Slepevic \& K. Paunovi. 2008. Nighttime Road-Traffic Noise and Arterial Hypertension in an Urban Population. Hypertension Research 31: 775-781.

Chávez, J.R. 2007. Ruido: Efectos sobre la salud y criterio de su evaluación al interior de recintos. Ciencia y Trabajo 8: 42-46.

De Kluizenaar, Y. \& S.A. Janssen. 2009. Long-term road traffic noise exposure is associated with an increase in morning tiredness. Journal of the Acoustic Society of America 126: 626-633.
Gómez, P., B. Pérez \& A. Meneses. 2008. Pérdidas auditivas relacionadas con la exposición al ruido en trabajadores de la construcción. Medicina Seguridad Trabajo 54: 33-40.

Guerrero, J., R. Cañedo, S. Rubio, M. Cutiño \& D. Fernández. 2006. Calidad de vida y trabajo: algunas consideraciones sobre el ambiente laboral de la oficina. Acimed 14: 1:5.

Hernández, H. \& M. Gutiérrez. 2006. Hipoacusia inducida por ruido, estado actual. Revista Cubana Médica Militar 35: 4-10.

La Torre, G., U. Moscato, F. La Torre, P. Ballini, S. Marchi \& W. Ricciardi. 2007. Environmental noise exposure and population health: a cross-sectional study in the Province of Rome. Journal of Public Health 15: 339-344.

Norma INTE 31-08-06-2000. Niveles de iluminación que deben tener los centros de trabajo. Instituto de Normas técnicas de Costa Rica, Instituto Nacional de Seguros, San José, Costa Rica.

Norma INTE 31-09-16-2000. Condiciones de seguridad e higiene en los centros de trabajo donde se genere ruido. Instituto 
de Normas técnicas de Costa Rica, Instituto Nacional de Seguros, San José, Costa Rica.

Otárola, F., F. O. Zapata, \& A. Finkelstein. 2008. Ruido laboral y su impacto en salud. Ciencia y trabajo 20: 47-51.

Rodríguez, L. \& J. Alonzo 2004. Efecto de los factores ambientales, laborales y psicosociales, en el síndrome del edificio enfermo. Ingeniería Revista Académica 8: 1-6.

Sánchez, M. \& A. Cristhian 2006. Estrategia frente a la problemática del ruido actual. Revista Ciencia y Salud 20:58-64.

Selander, J., G. Bluhm, T. Theorell, G. Pershagen, W. Babisch, I. Seiffert, D. Houthuijs, O. Breugelmans, F. Vigna-Taglianti, M.Antoniotti, E.Velonakis, E. Davou, M.Dudley, \& L. Järup. 2009. Saliva Cortisol and Exposure to Aircraft Noise in Six
European Countries. Environmental Health Perspectives 117:1713-1717.

Stansfeld, S. 2006. Exploring the Link Between Environmental Noise and Psychiatric Disorder. Psychiatric Times 23: 1-2.

Stevens, R.G. 2005. Circadian Disruption and Breast Cancer: From Melatonin to Clock Genes. Epidemiology 16: 254-258.

Su, S., C. Lu, J. Sheen, S. Kuo \& H. Guo. 2006. Tear secretion dysfunction among women workers engaged in lighton tests in the TFT-LCD industry. BMC Public Health 6:303-310.

Wang,Y.G. \& P.P. Zhang. 2007. Study on parking apron operation hazard management. Journal of Safety and Environment 7:131-133. 